\section{Phenotypic characterization of papaya genotypes to determine powdery mildew resistance}

\author{
Marcelo Vivas ${ }^{1 *}$, Silvaldo Felipe da Silveira ${ }^{2}$, Janieli Maganha \\ Silva Vivas' ${ }^{2}$ Pedro Henrique Dias dos Santos², Beatriz Murizi- \\ ni Carvalho' ${ }^{2}$, Rogério Figueiredo Daher ${ }^{1}$, Antonio Teixeira do \\ Amaral Júnior ${ }^{3}$, and Messias Gonzaga Pereira ${ }^{3}$
}

\begin{abstract}
In support of breeding of papaya (Carica papaya), the disease incidence and severity of powdery mildew (Ovulariopsis caricicola) were evaluated in papaya genotypes. Two experiments in complete randomized blocks were carried out, one in the field and the other in a greenhouse. In field experiments, the lowest mean disease incidence was observed on the genotypes 'Costa Rica' and 'Baixinho Super', and the lowest mean disease severity on 'Caliman M5', 'GTF', 'SH 11-08', and 'IS 11'. In the greenhouse experiment, the genotypes 'Caliman M5', 'Golden', 'Kapoho Solo', 'Waimanalo', 'Mamão Bené', 'SH 12-07', 'IS 12', and 'GTF' had the lowest mean incidence in at least one evaluation. On the other hand, for severity, the genotypes 'Diva', 'Sunrise Solo 72/12', 'Kapoho Solo PA', 'Waimanalo', 'Maradol', 'Maradol GL', 'SH 15-04', 'FMV, 'JS 12-4', 'SH 12-07' and 'Sekati FLM' had the lowest means. These results indicate these genotypes for a possible use in breeding for reduction of powdery mildew intensity.
\end{abstract}

Key words: Streptopodium caricae, Ovulariopsis caricicola, Carica papaya, genetic resistance.

\section{INTRODUCTION}

In Brazil and worldwide, papaya (Carica papaya L.) is an important tropical fruit. Today, Brazil ranks second in global production volume and third in acreage. Papaya is cultivated in several Brazilian states, of which Bahia, Espírito Santo, Ceará, Minas Gerais, and Rio Grande do Norte are the largest producers. On the other hand, the states of Espírito Santo, Rio Grande do Norte, Bahia, Ceará, and Paraíba are the largest papaya exporters (Treichel et al. 2016).

Despite the high production and consumption of Brazilian papaya, there are several restrictions to an expansion and even the maintenance of papaya plantations. These limitations are due mainly to the high incidence of pests and diseases (Rezende and Martins 2005, Suzuki et al. 2007, Martelleto et al. 2008). In this context, genebanks play an essential role, particularly with regard to the genetic variability required for plant breeding with a view to developing superior genotypes with different genetic constitutions. Wild species, landraces and obsolete cultivars may contain genes that confer better adaptation to environmental stresses, as well as resistance to numerous pests and diseases (Gepts 2006, Vivas et al. 2010, Vivas et al. 2012, Vivas et al. 2014). However, these genotypes maintained in genebanks should be described and evaluated
Crop Breeding and Applied Biotechnology 17: 198-205, 2017 Brazilian Society of Plant Breeding. Printed in Brazil http://dx.doi.org/10.1590/198470332017v17n3a31

\footnotetext{
*Corresponding author: E-mail:mrclvivas@hotmail.com
}

Received: 22 November 2016 Accepted: 16 December 2016

${ }^{1}$ Universidade Estadual do Norte Fluminense Darcy Ribeiro (UENF), Centro de Ciências e Tecnologias Agropecuárias, Laboratório de Engenharia Agrícola, 28.013-602, Campos dos Goytacazes, RJ, Brazil

${ }^{2}$ UENF, Laboratório de Entomologia e Fitopatologia

${ }^{3}$ UENF, Laboratório de Melhoramento Genético Vegetal , 
to deepen the knowledge about the different genotypes or gremplasms, before including them in breeding programs.

With regard to pest and diseases incidence, papaya is described as a host of four powdery mildew species in the world: Ovulariopsis papayae Van der Byl in South Africa, Phyllactinia caricaefolia Viégas in Brazil, Oidiopsis haplophylli (Magnus) Rulamort, anamorph of Leveillula taurica (Lév.) G. Arnaud in Australia, India and Portugal, and Ovulariopsis caricicola U. Braun, (syn. Streptopodium caricae Liberato \& R.W. Barreto) in Brazil (Liberato et al. 2004). According to these authors, powdery mildew symptoms of Streptopodium caricae species are commonly observed on papaya leaves in the northern region of Espírito Santo. According to Tatagiba et al. (2002), powdery mildew occurs year-round and chemical control is required in certain seasons to reduce symptoms. However, alternatives to the chemical control, e.g., genetic resistance, must also be developed.

The development of papaya varieties with superior agronomic traits, high fruit quality and a high level of disease resistance is a great challenge for crop breeders, because these traits have never been found in a single genotype. Knowledge about the genetic variability of the species available in the germplasm is a prerequisite for the indication of potential parents, to combine alleles related to traits of economic importance and guide crosses in breeding programs (Dias et al. 2011).

In papaya, the estimates of genetic parameters show the possibility of using simple breeding methods, such as mass selection for plant height, stem diameter, internode length, number of leaves, and leaf index (Foltran et al. 1993). With regard to the physiological seed quality, some traits are reported to have high heritability (Cardoso et al. 2009). Estimates of genetic parameters related to agronomic and fruit quality traits also indicate high chances for successful selection in segregating populations, due to the wide genotypic variability and high heritability (Silva et al. 2008).

However, for disease resistance, few such studies are available, in spite of their importance to subsidize the breeding programs targeting disease resistance. In this sense, the purpose of this study was to evaluate the potential of the varieties available in the UENF/CALIMAN germplasm collection for resistance to powdery mildew and to estimate genetic parameters in genotypes related to this disease.

\section{MATERIAL AND METHODS}

Two experiments were conducted, one in the field and the other in a greenhouse. The field experiment was conducted on the premises of the company Caliman Agricola S/A, in Linhares, Espírito Santo. The greenhouse experiment was installed on the campus 'Leonael Brizola' of Universidade Estadual do Norte Fluminense Darcy Ribeiro - UENF, in Campos dos Goytacazes, Rio de Janeiro, Brazil.

In the field trial, we evaluated the incidence and severity of powdery mildew on leaves. Disease severity was assessed on leaves with petiole attachment in the axil of newly opened flowers, on a diagrammatic scale for powdery mildew proposed by Santos et al. (2011), in December 2011 and February 2012. The experiment was arranged in a randomized complete block design with two replications, evaluting 59 genotypes. The experimental plots consisted of single rows with 15 plants each. Per unit, three scattered, non-neighboring plants, alternating between rows and excluding border plants were evaluated. For being a germplasm collection and to ensure fruit and seed production, fungicides recommended for the crop were occasionally sprayed. In the 60 days preceding the first evaluation, the active ingredients difenoconazole $(23 / 09)$ and mancozeb (07/04 and 19/12) were sprayed and mancozeb (02/02) and chlorothalonil (13/02) prior to the second evaluation.

The greenhouse experiment was arranged in a randomized complete block design with five replications per genotype and a total of 27 genotypes. Each experimental unit consisted of one plant per pot. Genotypes were transplanted into $5 \mathrm{~L}$ pots containing a 2:1:1 soil/sand/manure mixture, and maintained in the greenhouse. Natural inoculation was evidenced by the symptoms that appeared on the greenhouse plants. The incidence of leaves with powdery mildew symptoms as well as the disease severity on the leaves were evaluated. Severity was assessed in the seventh leaf from the stem base upwards, on a diagrammatic scale (Santos et al. 2011), in August, September and November 2011, and January 2012.

The data were subjected to analysis of variance, considering the genotypes as well as evaluation times, and the interaction between these two factors as source of variation. In case of a significant effect of the genotype $x$ time interaction, separate analyses were performed for each evaluation. When no significant effects of the interaction were 


\section{Vivas et al.}

detected, analyses were based on the mean of the two assessments. The genotype means were compared by Tukey's test at 0.05 probability.

For each variable, the following estimators and genetic parameters were calculated, considering the model effect as fixed: a) Mean phenotypic variance; b) Mean environmental variance; c) Quadratic component that expresses the mean genetic variability; d) Coefficient of genotypic determination, based on the genotype mean; and, e) Variation index (Cruz et al. 2012). For the genetic analysis, the software package Genes was used (Cruz 2013).

\section{RESULTS AND DISCUSSION}

In both experiments, effects of the genotype $x$ evaluation time interaction on disease incidence and severity were detected, so individual analyses were performed for each evaluation time. The significant effects of the interaction suggest differentiated performance of the genotypes in response to environmental changes. According to Cruz et al. (2012), this different behavior is caused by genotype-specific physiological and biochemical factors. In the individual analyses of the field plants, a significant genotype effect for powdery mildew incidence was only observed in the first and for severity in the second evaluation. In the individual analyses in the greenhouse, we observed the effect of powdery mildew severity only in the first and third evaluations, while significant differences between genotypes were observed in all periods for disease incidence.

The above results proved genetic variability among the genotypes of the germplasm collection of UENF/CALIMAN with regard to resistance to $O$. caricicola. However, the variations between experiments and evaluations must be analyzed. For powdery mildew incidence, leaves of greenhouse plants with disease symptoms were evaluated. The
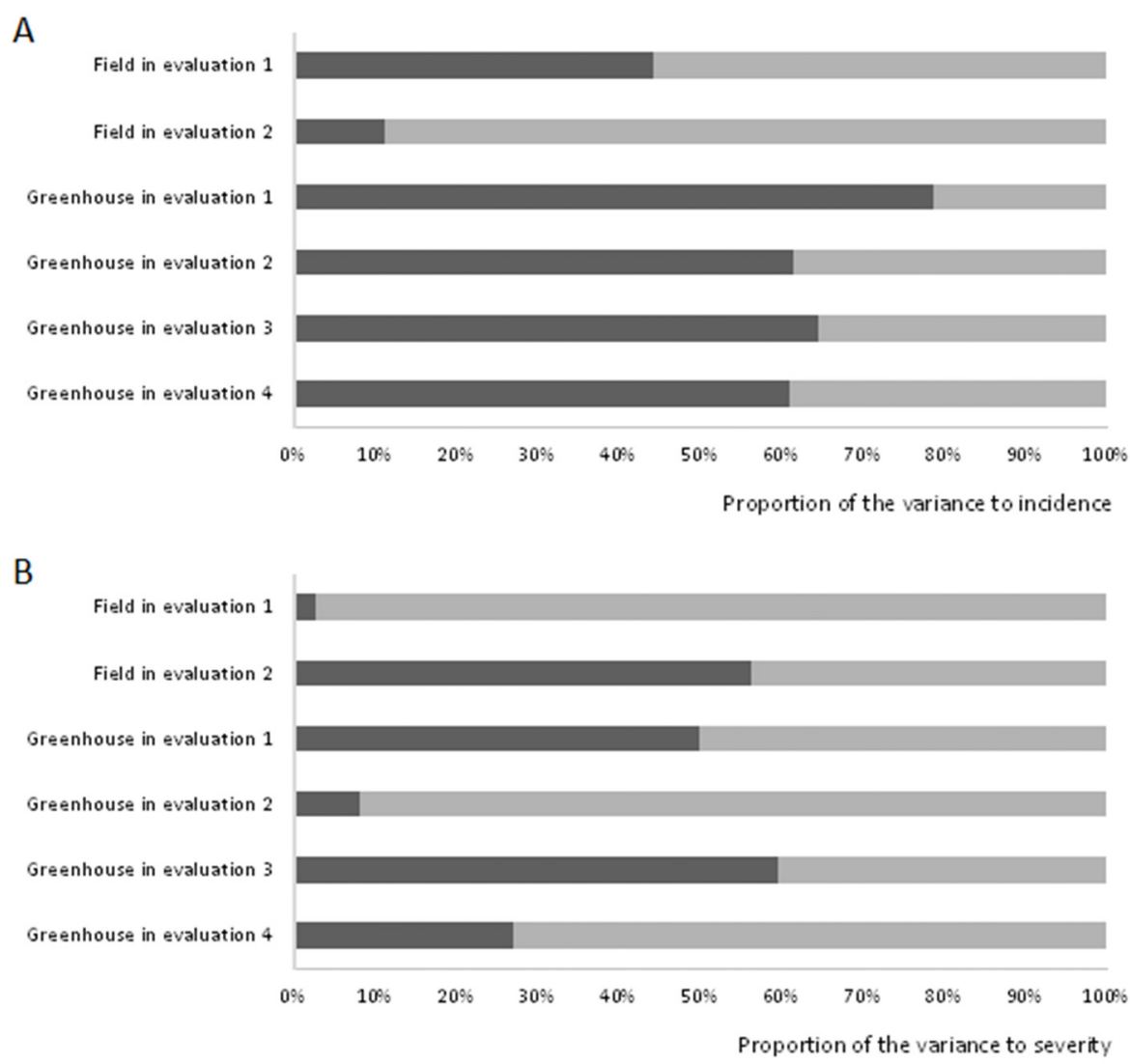

Figure 1. Proportion of the mean environmental variance (light bars) and quadratic component that expresses the mean genetic variability (dark bars) in phenotypic variation, obtained in distinct evaluation times in the field and greenhouse, for powdery mildew incidence $(A)$ and severity $(B)$ on papaya leaves. 
genetic variance detected was greater than the environmental variance, i.e., has higher discriminating power (Figure 1). This scenario was repeated for powdery mildew severity on leaves of field plants in the second evaluation, and of greenhouse plants in the first and third evaluations (Figure 1). Aside from information about the genotypic variance, estimates of genetic parameters such as heritability and variation index are highly relevant for breeding, for guiding the choice of the breeding method most indicated for the crop and allowing inferences on estimates of selection gains. When the heritability $\left(\mathrm{h}^{2}\right)$ values exceed $80 \%$ and the variation index is greater than unity, selection with satisfactory gains is possible (Falconer 1987).

In this study, heritability varied from 11.33 to 78.70 for disease incidence and from 2.27 to 59.58 for severity (Figure 2 ), indicating the possibility of selecting genotypes with low disease levels. For the genetic parameters related to the physiological seed quality of genotypes of the UENF/CALIMAN papaya germplasm collection, Cardoso et al. (2009) found low heritability estimates and variation indices in a greenhouse evaluation of germination percentage, and germination speed index. On the other hand, significant heritability values $\left(\mathrm{h}^{2}\right)$ and index of variation (IV) were found for 1000-seed weight, percentage of germinated seeds, root length, and seedling dry and fresh weight, indicating the possibility of significant gains with selection for seed quality. With regard to resistance to black spot (Asperisporium caricae), moderate heritability estimates were found for black spot severity in the tested progenies of a papaya landrace (Vivas et al. 2012).

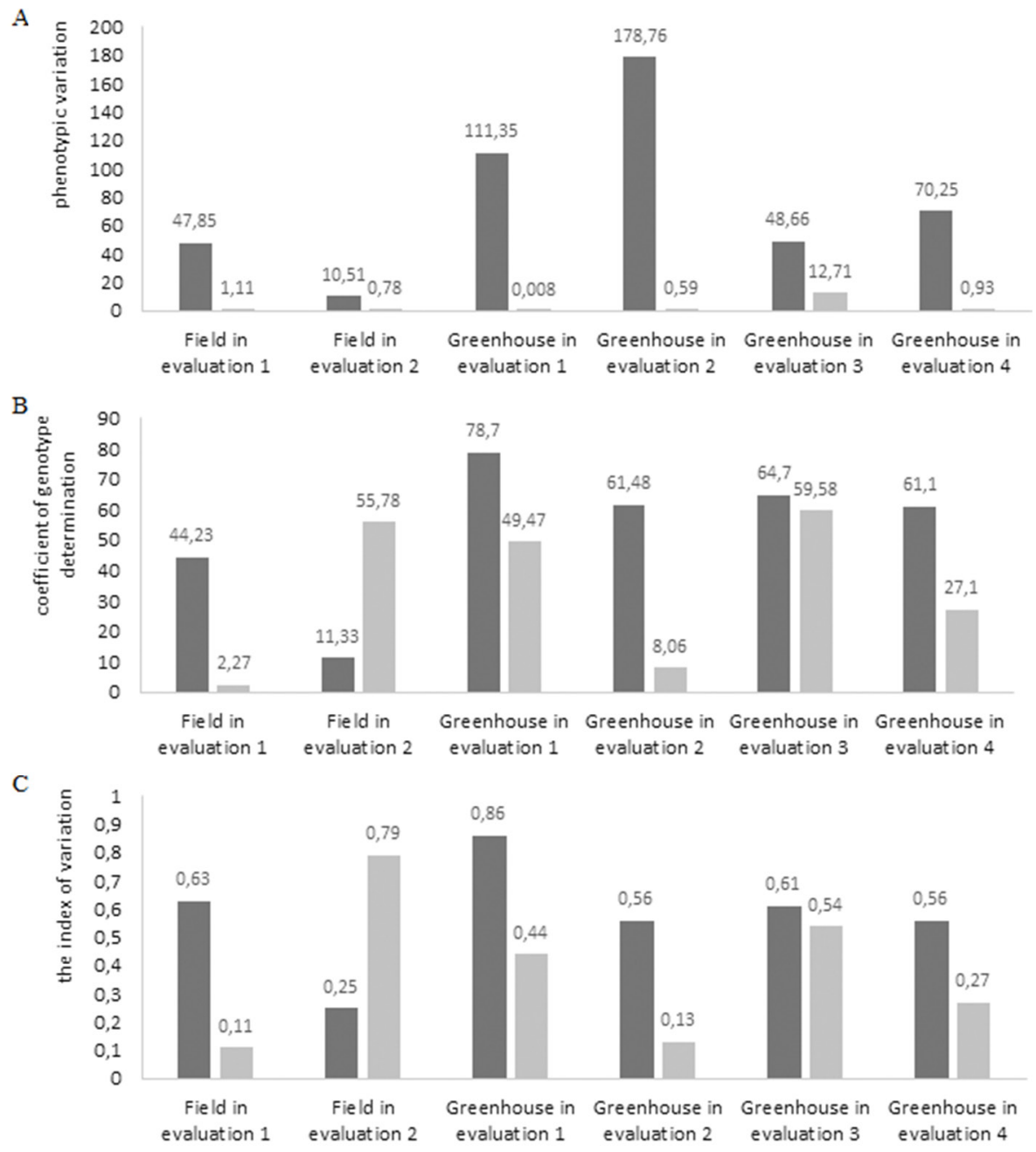

Figure 2. Estimation of the phenotypic variation mean (A), coefficient of genotype determination based on the genotype mean (B) and the index of variation (C). Estimates obtained in field and greenhouse evaluations and distinct periods, for powdery mildew to incidence (dark bars, on the left) and severity (light bars, on the right) on papaya leaves. 
The lowest mean variability for leaf severity of powdery mildew symptoms in the field was observed for the genotypes 'Costa Rica' and 'Baixinho Super'. The means of the other 42 genotypes differed from the genotype with lowest mean severity ('Taiwan et') (Table 1). For powdery mildew incidence, the means of the genotypes 'Caliman M5', 'GTF', 'SH

Table 1. Means of powdery mildew severity and incidence on leaves with symptoms of the disease of papaya genotypes of the germplasm collection of UENF/CALIMAN

\begin{tabular}{|c|c|c|c|c|c|c|c|c|c|}
\hline \multirow{2}{*}{\multicolumn{2}{|c|}{ Genotype }} & \multicolumn{4}{|c|}{ Severity } & \multicolumn{4}{|c|}{ Incidence } \\
\hline & & \multicolumn{2}{|c|}{ Evaluation 1} & \multicolumn{2}{|c|}{ Evaluation 2} & \multicolumn{2}{|c|}{ Evaluation 1} & \multicolumn{2}{|c|}{ Evaluation 2} \\
\hline 1 & ‘Caliman M5’ & 1.40 & a & 1.63 & $\mathrm{bc}$ & 5.65 & $\mathrm{bc}$ & 87.15 & $\mathrm{a}$ \\
\hline 2 & 'Sunrise Solo 783' & 0.57 & a & 0.74 & bc & 16.68 & $a-c$ & 79.67 & a \\
\hline 3 & 'Costa Rica' & 2.27 & a & 0.12 & $c$ & 17.01 & $a-c$ & 81.23 & a \\
\hline 4 & 'Taiwan et' & 0.45 & a & 5.25 & a & 19.10 & $a-c$ & 88.31 & a \\
\hline 5 & ‘Diva' & 2.33 & a & 0.49 & bc & 10.40 & $a-c$ & 82.88 & a \\
\hline 7 & 'Sunrise Solo' & 2.84 & a & 0.87 & bc & 7.99 & $a-c$ & 83.96 & a \\
\hline 8 & 'Caliman AM' & 3.50 & a & 0.78 & bc & 26.23 & $a-c$ & 76.72 & a \\
\hline 9 & 'Caliman GB' & 2.45 & a & 2.00 & $a-c$ & 11.45 & $a-c$ & 87.30 & a \\
\hline 10 & ‘Caliman SG' & 3.90 & a & 1.87 & $a-c$ & 9.01 & $a-c$ & 83.15 & a \\
\hline 11 & 'Golden' & 3.50 & a & 0.87 & bc & 10.08 & $a-c$ & 87.61 & a \\
\hline 16 & 'Tailândia' & 0.43 & a & 0.80 & bc & 15.42 & $a-c$ & 81.99 & a \\
\hline 17 & 'São Mateus' & 2.07 & a & 1.34 & bc & 25.60 & $a-c$ & 84.54 & a \\
\hline 18 & 'Kapoho Solo PV' & 1.00 & a & 0.47 & bc & 10.89 & $a-c$ & 82.22 & a \\
\hline 19 & 'Sunrise Solo PT' & 3.17 & a & 0.97 & bc & 10.33 & $a-c$ & 83.32 & a \\
\hline 20 & 'Waimanalo' & 0.29 & a & 0.70 & bc & 8.33 & $a-c$ & 84.69 & a \\
\hline 21 & ‘Mamão Bené’ & 2.62 & a & 2.19 & $a-c$ & 19.33 & $a-c$ & 86.51 & a \\
\hline 22 & ‘Mamão Roxo’ & 1.35 & a & 1.85 & $a-c$ & 21.54 & $a-c$ & 87.77 & a \\
\hline 23 & 'Maradol' & 0.35 & a & 1.85 & $a-c$ & 16.67 & $a-c$ & 87.77 & a \\
\hline 24 & 'Maradol GL' & 1.23 & a & 1.60 & bc & 13.73 & $a-c$ & 87.61 & a \\
\hline 33 & ‘GTF’' & 1.22 & a & 1.05 & bc & 1.71 & $\mathrm{c}$ & 82.64 & a \\
\hline 34 & 'STZ - 03' & 1.84 & a & 0.39 & $b c$ & 21.80 & $a-c$ & 80.25 & a \\
\hline 35 & 'SH 12-07' & 1.84 & a & 1.50 & bc & 16.97 & $a-c$ & 82.98 & a \\
\hline 36 & 'SH 11-08' & 0.42 & a & 1.22 & bc & 6.00 & $\mathrm{bc}$ & 88.21 & a \\
\hline 37 & 'SH 50-09' & 2.97 & a & 2.07 & $a-c$ & 21.72 & $a-c$ & 81.40 & a \\
\hline 38 & 'SH 02-01' & 2.14 & a & 1.10 & $\mathrm{bc}$ & 14.19 & $a-c$ & 80.94 & a \\
\hline 39 & 'SH 14-05' & 3.50 & a & 1.45 & $\mathrm{bc}$ & 16.77 & $a-c$ & 83.81 & a \\
\hline 40 & 'SH 15-04' & 1.37 & a & 3.95 & $a b$ & 18.94 & $a-c$ & 86.25 & a \\
\hline 41 & 'SH 04-02' & 1.14 & a & 0.63 & bc & 12.82 & $a-c$ & 83.72 & $a$ \\
\hline 42 & 'SH 12-06' & 0.52 & a & 0.57 & $b c$ & 11.95 & $a b$ & 79.25 & $a$ \\
\hline 43 & 'Papaya 42' & 2.17 & a & 1.87 & $a-c$ & 7.85 & $a b$ & 88.17 & a \\
\hline 44 & 'Papaya 45’ & 0.07 & a & 2.14 & $a-c$ & 36.40 & $a b$ & 86.42 & a \\
\hline 45 & 'Papaya 46’ & 1.62 & a & 1.24 & bc & 15.88 & $a b$ & 84.37 & a \\
\hline
\end{tabular}


Table 1. (cont)

\begin{tabular}{|c|c|c|c|c|c|c|c|c|c|}
\hline 46 & 'FMV' & 0.38 & a & 1.37 & bc & 13.46 & $a b$ & 87.69 & a \\
\hline 47 & 'Golden R' & 2.33 & a & 1.34 & bc & 17.08 & $a b$ & 84.22 & a \\
\hline 48 & 'JS 11’ & 0.02 & a & 2.84 & $a-c$ & 5.81 & $b$ & 89.00 & a \\
\hline 49 & 'Tainung' & 1.68 & a & 0.83 & bc & 8.21 & $a b$ & 82.29 & a \\
\hline 50 & 'STZ 23 PL' & 2.27 & a & 1.34 & $b c$ & 10.50 & $a b$ & 85.96 & a \\
\hline 51 & 'STZ - 63' & 2.47 & $\mathrm{a}$ & 1.10 & bc & 8.57 & $a-c$ & 82.81 & a \\
\hline 52 & 'Sekati FLM' & 3.42 & a & 0.58 & bc & 13.29 & $a-c$ & 84.07 & a \\
\hline 55 & 'THB STZ 39' & 2.17 & a & 0.87 & bc & 7.72 & $a-c$ & 86.04 & a \\
\hline 56 & ‘G39 03-02’ & 1.69 & a & 0.42 & $b c$ & 21.08 & $a-c$ & 81.02 & a \\
\hline 57 & 'B5' & 0.57 & $\mathrm{a}$ & 0.46 & $\mathrm{bc}$ & 18.04 & $a-c$ & 85.04 & a \\
\hline 58 & ‘FG' & 0.93 & a & 1.55 & bc & 6.29 & $a-c$ & 77.48 & a \\
\hline
\end{tabular}

* For the same variable, means followed by the same letter represent a statistically homogeneous group by the Tukey test at 0.05 of probability.

Table 2. Comparison of genotype means for leaf incidence of powdery mildew symptoms of greenhouse plants in three evaluations

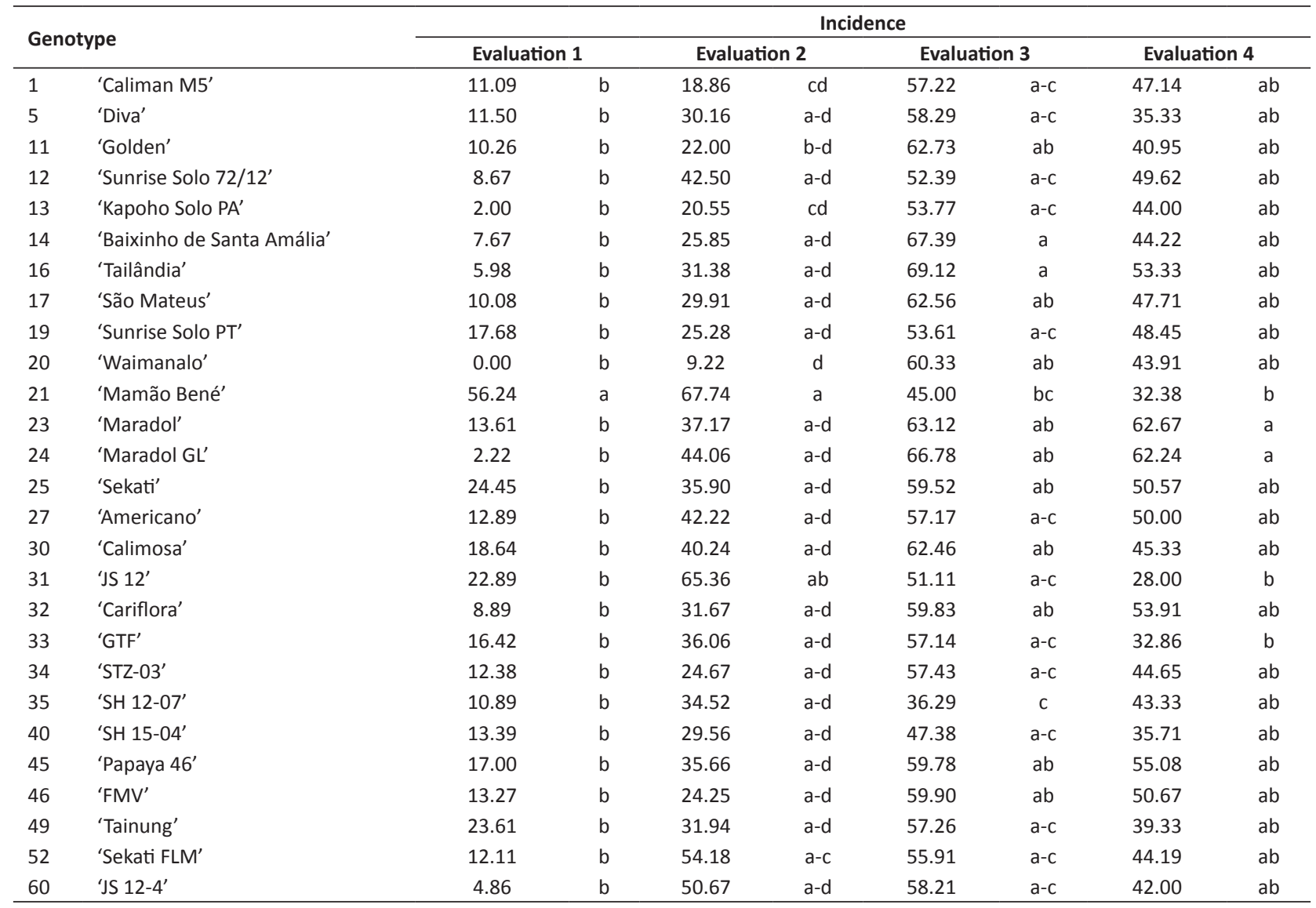

* For the same variable, means followed by the same letter belong to a statistically homogeneous group by the Tukey test at 0.05 of probability. 


\section{$M$ Vivas et al.}

$11-08$ ' and 'JS 11' differed from the genotypes with lowest means. For an intermediate group of 46 cultivars, the mean between susceptible and resistant genotypes was not significantly different (Table 1).

In the first evaluation of powdery mildew incidence based on leaf symptoms of greenhouse plants, all genotypes except 'Mamão Bené' had a low mean disease intensity. In the second evaluation, the genotypes 'Caliman M5', 'Golden', 'Kapoho Solo' and 'Waimanalo' had means that differed from the most susceptible genotype ('Mamão Bené'). In the third evaluation, 'Mamão Bené' and 'SH 12-07' had means that differed from 'Thailand' and 'Baixinho de Santa Amália' (genotypes with lowest mean disease intensity). Again, genotype 'Mamão Bené' belonged to the group with the lowest mean, and in addition, 'JS 12' and 'GTF' had means that differed from the genotypes with highest mean disease intensity (Table 2).

Compared with the previous results, different effects of genotypes at different evaluation times can be observed, especially for genotype 'Mamão Bené'. According to Cruz et al. (2012), this different performance is caused by genotypespecific physiological and biochemical factors. The aforementioned genotype 'Mamão Bené' was rather susceptible in the first and second evaluations, however, in the last two it was grouped with the genotypes with lowest disease incidence. This fact allows the assumption that plant age may affect the pathogen resistance/susceptibility of a genotype. However, further studies are required to investigate this presumption. Similar mechanisms were also reported in other pathosystems (Rava et al. 1999, Costa et al. 2006).

In the greenhouse evaluations of powdery mildew severity, a significant genotype effect was observed in the first and third evaluations. The results for genotype 'Mamão Bené' were similar to those mentioned above. In the first

Table 3. Comparison of genotype means for powdery mildew severity on papaya leaves of greenhouse plants in three evaluations

\begin{tabular}{|c|c|c|c|c|c|c|c|c|c|}
\hline \multirow{2}{*}{\multicolumn{2}{|c|}{ Genotype }} & \multicolumn{8}{|c|}{ Severity } \\
\hline & & \multicolumn{2}{|c|}{ Evaluation 1} & \multicolumn{2}{|c|}{ Evaluation 2} & \multicolumn{2}{|c|}{ Evaluation 3} & \multicolumn{2}{|c|}{ Evaluation 4} \\
\hline 1 & 'Caliman M5’ & 0.01 & $a b$ & 0.24 & $\mathrm{a}$ & 13.10 & $a b$ & 1.10 & a \\
\hline 5 & 'Diva' & 0.00 & $\mathrm{~b}$ & 0.84 & a & 8.58 & $a b$ & 1.49 & a \\
\hline 11 & 'Golden' & 0.04 & $a b$ & 0.18 & a & 5.80 & $a b$ & 0.74 & a \\
\hline 12 & 'Sunrise Solo 72/12' & 0.00 & $\mathrm{~b}$ & 0.17 & a & 9.00 & $a b$ & 0.82 & a \\
\hline 13 & ‘Kapoho Solo PA' & 0.00 & $\mathrm{~b}$ & 0.10 & a & 4.44 & $a b$ & 4.52 & a \\
\hline 14 & 'Baixinho de Santa Amália' & 0.00 & $b$ & 0.18 & a & 10.50 & $a b$ & 1.98 & a \\
\hline 16 & 'Tailândia' & 0.02 & $a b$ & 0.04 & a & 12.04 & $a b$ & 1.78 & a \\
\hline 17 & 'São Mateus' & 0.02 & $a b$ & 0.39 & a & 11.04 & $a b$ & 1.32 & a \\
\hline 19 & 'Sunrise Solo PT' & 0.10 & $a b$ & 0.02 & $\mathrm{a}$ & 7.30 & $a b$ & 1.92 & $\mathrm{a}$ \\
\hline 20 & 'Waimanalo' & 0.00 & $\mathrm{~b}$ & 0.12 & $\mathrm{a}$ & 7.50 & $a b$ & 0.90 & $\mathrm{a}$ \\
\hline 21 & 'Mamão Bené' & 0.34 & $\mathrm{a}$ & 0.84 & $\mathrm{a}$ & 5.40 & $a b$ & 1.38 & $\mathrm{a}$ \\
\hline 23 & 'Maradol' & 0.00 & $b$ & 0.62 & $\mathrm{a}$ & 8.96 & $a b$ & 0.64 & $\mathrm{a}$ \\
\hline 24 & 'Maradol GL' & 0.00 & $b$ & 0.28 & $\mathrm{a}$ & 3.90 & $a b$ & 1.66 & $\mathrm{a}$ \\
\hline 25 & 'Sekati' & 0.02 & $a b$ & 0.42 & $\mathrm{a}$ & 2.30 & $a b$ & 1.17 & $\mathrm{a}$ \\
\hline 27 & 'Americano' & 0.03 & $a b$ & 0.56 & $\mathrm{a}$ & 3.80 & $a b$ & 1.10 & a \\
\hline 30 & 'Calimosa' & 0.04 & $a b$ & 2.12 & $\mathrm{a}$ & 10.64 & $a b$ & 2.04 & a \\
\hline 31 & 'JS 12' & 0.28 & $a b$ & 0.92 & a & 7.74 & $a b$ & 1.14 & a \\
\hline 32 & 'Cariflora' & 0.06 & $a b$ & 0.96 & a & 3.90 & $a b$ & 1.52 & a \\
\hline 33 & 'GTF' & 0.02 & $a b$ & 0.14 & $\mathrm{a}$ & 5.68 & $a b$ & 2.94 & a \\
\hline 34 & 'STZ - 03' & 0.02 & $a b$ & 0.04 & $\mathrm{a}$ & 2.60 & $a b$ & 1.10 & a \\
\hline 35 & 'SH 12-07' & 0.02 & $a b$ & 0.10 & $\mathrm{a}$ & 1.76 & $b$ & 0.50 & a \\
\hline 40 & 'SH 15-04' & 0.00 & $\mathrm{~b}$ & 2.36 & $\mathrm{a}$ & 4.96 & $a b$ & 0.54 & $\mathrm{a}$ \\
\hline 45 & 'Papaya 46’ & 0.10 & $a b$ & 0.66 & $\mathrm{a}$ & 9.80 & $a b$ & 1.90 & a \\
\hline 46 & 'FMV' & 0.00 & $b$ & 0.48 & $\mathrm{a}$ & 14.00 & $\mathrm{a}$ & 3.22 & $\mathrm{a}$ \\
\hline 49 & 'Tainung' & 0.22 & $a b$ & 0.73 & a & 6.56 & $a b$ & 0.32 & $\mathrm{a}$ \\
\hline 52 & 'Sekati FLM' & 0.10 & $a b$ & 0.28 & $\mathrm{a}$ & 1.58 & $\mathrm{~b}$ & 0.27 & $\mathrm{a}$ \\
\hline 60 & 'JS 12-4’ & 0.00 & $\mathrm{~b}$ & 2.66 & $\mathrm{a}$ & 10.80 & $a b$ & 0.32 & a \\
\hline
\end{tabular}

* For the same variable, means followed by the same letter belong to a statistically homogeneous group by the Tukey test at 0.05 of probability. 
assessment, this genotype had the highest mean severity, however, in the third assessment, it formed an intermediate group (Table 3). The group with lowest severity was formed by the genotypes 'Diva', 'Sunrise Solo 72/12', 'Kapoho Solo PA', 'Waimanalo', 'Maradol', 'Maradol GL', 'SH 15-04', 'FMV', and 'JS 12-4' in the first evaluation. In the third evaluation, 'SH 12-07' and 'Sekati FLM' had the lowest disease severity levels (Table 3).

These results are promising for the selection of superior genotypes, with considerable reductions of powdery mildew incidence and/or severity. Of the tested genotypes, 'Maradol', 'Maradol GL', 'Caliman M5', and 'GTF' stood out with lowest mean disease intensity in field and greenhouse. These genotypes can be used in crosses and selection to develop lines and/or hybrids, which aside from the traits of resistance to the above disease, also have agronomic traits of interest such as fruit yield and quality from the agricultural point of view.

\section{ACKNOWLEDGEMENTS}

The authors thank the Darcy Ribeiro North Fluminense State University - UENF and the Fundação Carlos Chagas Filho de Amparo à Pesquisa do Estado do Rio de Janeiro (FAPERJ) - FAPERJ, for financial support. The authors also thank the Caliman Agrícola S/A for financial and logistical support.

\section{REFERENCES}

Cardoso DL, Silva RF, Pereira MG, Viana AP and Araújo EF (2009) Diversidade genética e parâmetros genéticos relacionados à qualidade fisiológica de sementes em germoplasma de mamoeiro. Revista Ceres 56: 572-579.

Costa IFD, Balardin RS, Medeiros LA and Bayer TM (2006) Resistência de seis cultivares de soja ao Colletotrichum truncatum (Schwein) em dois estádios fenológicos. Ciência Rural 36: 1684-1688.

Cruz CD (2013) GENES: A software package for analysis in experimental statistics and quantitative genetics. Acta Scientiarum Agronomy 35: 271-276.

Cruz CD, Regazzi AJ and Carneiro PC (2012) Métodos biométricos aplicados ao melhoramento genético. Editora UFV, Viçosa, 512p.

Dias NLP, Oliveira EJ and Dantas JLL (2011) Avaliação de genótipos de mamoeiro com uso de descritores agronômicos e estimação de parâmetros genéticos. Pesquisa Agropecuária Brasileira 46: 14711479.

Falconer DS (1987) Introduction to quantitative genetics. Longman, London, 340p.

Foltran DE, Gonçalves PS, Sabino JC, Igue T and Vilela RCF (1993) Estimativas de parâmetros genéticos e fenotípicos em mamão. Bragantia 52: 7-15.

Gepts P (2006) Plant genetic resources conservation and utilization: the accomplishments and future of a societal insurance policy. Crop Science 46: 2278-2296.

Liberato JR, Barreto RW and Louro RP (2004) Streptopodium caricae $\mathrm{sp}$. nov, with a discussion on powdery mildew of papaya and an emended description of the genus Streptopodium and of Oidium caricae. Mycological Research 108: 1185-1194.

Martelleto LAP, Ribeiro RLD, Surdo-Martelleto M, Vasconcellos MAS, Marin SLD and Pereira MB (2008) Cultivo orgânico do mamoeiro 'Baixinho de Santa Amália' em diferentes ambientes de proteção.
Revista Brasileira de Fruticultura 30: 662-666.

Rava CA, Costa JGC and Andrade EM (1999) Influência da idade da planta de feijoeiro comum na resistência à antracnose. Pesquisa Agropecuária Gaúcha 5: 325-330.

Rezende JAM and Martins MC (2005) Doenças do mamoeiro (Carica papaya L.). In Kimati H, Amorim L, Rezende JAM, Bergamin Filho A and Camargo LEA (eds) Manual de fitopatologia: Doenças das plantas cultivadas. Agronômica Ceres, São Paulo, p. 435-443.

Santos PHD, Vivas M, Silveira SF, Silva JM and Terra CEPS (2011) Elaboração e validação de escala diagramática para avaliação da severidade de oídio em folhas de mamoeiro. Summa Phytopathologica 37: 215-217.

Silva FF, Pereira MG, Ramos HCC, Damasceno Junior PC, Pereira TNS, Gabriel APC, Viana AP, Daher RF and Ferreguetti GA (2008) Estimation of genetic parameters related to morpho-agronomic and fruit quality traits of papaya. Crop Breeding and Applied Biotechnology 8: 65-73.

Suzuki MS, Zambolim L and Liberato JR (2007) Progresso de doenças fúngicas e correlação com variáveis climáticas em mamoeiro. Summa Phytopathologica 33: 167-177.

Tatagiba JT, Liberato JR, Zambolim L, Costa H and Ventura JA (2002) Controle químico do oídio do mamoeiro. Fitopatologia Brasileira 27: 219-222.

Treichel M, Kist BB and Santos CE (2016) Anuário brasileiro da fruticultura. Editora Gazeta Santa Cruz, Santa Cruz do Sul, 88p.

Vivas M, Silveira SF, Terra CEPS and Pereira MG (2010) Reação de germoplasma e híbridos de mamoeiro à mancha-de-phoma (Phoma caricae-papayae) em condições de campo. Tropical Plant Pathology 35: 323-328.

Vivas M, Silveira SF, Vivas JMS and Pereira MG (2012) Patometria, parâmetros genéticos e reação de progênies de mamoeiro à pintapreta. Bragantia 71: 235-238.

Vivas M, Silveira SF, Vivas JMS, Viana AP, Amaral Junior AT and Pereira MG (2014) Seleção de progênies femininas de mamoeiro para resistência a mancha-de-phoma via modelos mistos. Bragantia 73: 446-450. 